Article

\title{
Reframing the History of American Genealogy: On the Paradigm of Democratization and the Capitalization of Longing
}

\author{
Adam Hjorthén (1)
}

check for updates

Citation: Hjorthén, Adam. 2022. Reframing the History of American Genealogy: On the Paradigm of Democratization and the Capitalization of Longing. Genealogy 6: 21. https://doi.org/10.3390/ genealogy6010021

Received: 7 December 2021

Accepted: 3 March 2022

Published: 7 March 2022

Publisher's Note: MDPI stays neutral with regard to jurisdictional claims in published maps and institutional affiliations.

Copyright: (C) 2022 by the author. Licensee MDPI, Basel, Switzerland. This article is an open access article distributed under the terms and conditions of the Creative Commons Attribution (CC BY) license (https:// creativecommons.org/licenses/by/ $4.0 /)$.
Swedish Institute for North American Studies, Department of English, Uppsala University, 75238 Uppsala, Sweden; adam.hjorthen@engelska.uu.se

\begin{abstract}
Genealogy is one of the most popular sociocultural pursuits in modern U.S. history. During recent decades, scholars of the history of American genealogy and family history have forwarded an argument that its development since the 19th century is characterized by "democratization". Surveying the scholarship, this article critically examines what that argument really means, what it unveils about historical change, and what it does not adequately recognize. The article argues that "democratization" is inadequate for making precise explanations about historical causes, causalities, and consequences. As an alternative to the democratization argument, it is suggested that research on the history of American genealogy should be inspired by recent studies of contemporary genealogy by sociologists, anthropologists, and cultural geographers, as well as by philosophical studies on the human longing for ancestry. By doing so, it becomes possible to engage with the crucial question of power in the historical inquiry. This approach is explored through the genealogical work of the Church of Jesus Christ of Latter-day Saints. Rather than looking at genealogy through the lens of grassroots individuals, we need to acknowledge the connection between personal longing for ancestry and the ways in which powerful organizations, institutions, media, and businesses have sought to capitalize on this longing.
\end{abstract}

Keywords: history of genealogy; family history; United States; democratization; longing for ancestry; media and infrastructure; Church of Jesus Christ of Latter-day Saints

\section{Introduction}

Scholars and media alike have claimed that genealogy is booming in the United States, that Americans are experiencing a "genealogy craze", and that genealogy today is "almost as popular as porn" (Barnwell 2013; Rodriguez 2014). Observations about an American genealogy or family history boom have, however, been made many times before, such as in the 1920s and 1970s. Given its impact and longevity, it is safe to say that genealogy constitutes one of the most important sociocultural pursuits in modern U.S. history (Phillips 1923; Everybody's Search for Roots 1978). As historian François Weil pointed out in 2013, however, it also remains one of the least studied. In his useful book Family Trees, a history of genealogy in the United States from the 17th century to today, Weil noted that "genealogy is arguably the element of contemporary American culture about which we know the least", and that "the history of genealogy remains largely to be written" (Weil 2013, p. 2). This claim is likewise not new; it was in fact made-close to verbatim-in 1986 by historians Robert Taylor and Ralph Crandall (Taylor and Crandall 1986, p. 4).

There are several factors that explain the relative scholarly inattention to the history of genealogy. First, the perceived distance between academic history and genealogical research has grown since the 1980s. There was a degree of cooperation between genealogists and academic historians in the 1960s and 1970s, centering on a shared interest in biographic, demographic, and social history. With the introduction of new critical perspectives, marked by cultural and linguistic turns, academic scholars became less inclined to use demographic and biographic sources, and moved away from the positivist approach to history that 
continued to define genealogical research (Taylor and Crandall 1986; Hershkovitz 2016). Historians engaged in microhistory, local history, and the prospects of DNA have since the 1990s slowly begun to close that gap, exemplified by the academic study of, and public controversy surrounding, Thomas Jefferson and the children of Sally Hemings (e.g., Gordon-Reed 2008). Second, as historian Karin Wulf has argued in a study of lineage and family history in colonial British America, the contemporary status of genealogy and its position as a widespread hobby have obscured the significance of past genealogical cultures and practices (Wulf 2012, p. 500). Considering that popular genealogy first took root in the mid-19th century United States, and that U.S. organizations, businesses, and media have been instrumental in propelling its international spread, this silence has been noteworthy.

It is only in recent years that scholars have attempted to make sense of the history of American genealogy, and their predominant mode of inquiry has been to center the people involved in the genealogical endeavor-amateur and professional boosters and researchers. Through this approach, historians have forwarded the argument that the modern history of genealogy is characterized by "democratization". Surveying the scholarship, the concept of democratization is so frequently adopted in conjunction with the development of genealogy that their relationship apparently prompts no further explanation. Scholars have, for example, written about the "democratization of genealogical research" (Lenstra 2015, p. 203), a "democratize[d] access to the past" (De Groot 2015, p. 119), "a democratization of sources" for genealogical research (Tucker 2016, p. 165), "a democratic and expanded notion of relatedness" (Creet 2020, p. 168), and a "democratic interest in family history" (Weil 2013, p. 181). A common use of the term refers to the changing demographics of family historians and the popularization of genealogy, especially in relation to post-1970s African American genealogy (Hareven 1978; Taylor 1982; Bidlack 1983, p. 9; Morgan 2010a, p. 144). In the most recent book-length addition to the historiography of U.S. genealogy, Francesca Morgan's A Nation of Descendants, Alexis de Tocqueville and the notion of "democracy-minded Americans" serves as a narrative point of departure and a contrast to the analysis of the politics of genealogy, articulated for example through scientific racism, genetic determinism, and commercial commodification (Morgan 2021, p. 1). It is perhaps not surprising that the notion of democratized genealogy appears so often in relation to American genealogy, as it marks a clear republican break with European aristocratic traditions. In the words of one of the founding figures of modern American genealogy, Donald Lines Jacobus, writing in 1930, one easily gets the sense that "Genealogy has become in America truly democratic" (Jacobus [1930] 1968, p. 9).

This article examines what the argument of democratization really means, what it unveils about historical change, and what it does not adequately recognize. Precisely because it is such an evocative concept, we need to critically engage the theoretical presuppositions of the paradigm. First, it is difficult to know exactly what democratization entails in the historical scholarship on genealogy, since it is regularly used without being defined. Democratization may often be used as a stand-in for egalitarianism, but since it also concerns the relocation of power, it implicitly suggests a redistribution of influence in the genealogical landscape. As a consequence of inarticulation, the concept not only becomes analytically vague, but also inadequate for making precise explanations about historical causes, causalities, and consequences. Second, there is an unarticulated epistemological feedback loop inherent in the methodology of the democratization paradigm, where the focus on the individual actors of the genealogical landscape produces interpretations that the driving force of its historical change has been individual actors. The methodological centering of individual genealogists and boosters thus needs to be reappraised. Third, precisely because democratization is such an evocative concept, and given its adoption without a clear definition, democratization regularly becomes a signifier for describing a positive sense of change; it is intrinsically related to a narrative of modernization, and to a notion of history as progress.

Offering an alternative to the democratization argument, I believe that research on genealogical history should be inspired by results from recent studies of contemporary 
genealogy by sociologists, anthropologists, and cultural geographers, as well as by philosophical studies on the human longing for ancestry (see also Morgan 2021, p. 6). By doing so, it becomes possible to engage with the crucial question of power in the historical inquiry. Rather than looking at genealogy through the lens of grassroots individuals, we need to acknowledge and theorize the intimate connection between personal longing for ancestry and the ways in which powerful organizations, institutions, media, businesses, and states have sought to capitalize on this longing. Although their reasons have varied-economic, sociocultural, or religious - these actors have shared a desire for profit, whether today, in the future, or in the afterlife. The efforts of powerful actors have been directed at people's individual longing for ancestry, serving to strengthen it through infrastructural investments, and solidifying it through the work of rhetoric. This is a process that I propose to call the capitalization of longing. Although it has often followed the logic of capitalism, the process of capitalization as defined here is connected to broader notions of profit. As a result of this process, genealogy today appears as a natural phenomenon-a force of human nature that is both inevitable and a sign of modern progression.

In the final sections of this article, I will illustrate how "longing" and "capitalization" have combined to make modern genealogy through the case of the Church of Jesus Christ of Latter-day Saints (the LDS Church). To Mormons and the LDS Church, genealogy is a religious practice grounded in the belief that family is eternal. The LDS Church is a fitting illustration of the process of capitalized longing, for two reasons: First, it is the organization that has invested by far the most energy and money on developing genealogy, in the United States and worldwide. Second, and given the LDS Church's religious mandate for genealogy, it is also a case where one would assume that the Mormon community itself would have been a driving force behind the LDS Church's genealogical work; as it turns out, it has not been so simple. Before I move on to that discussion, however, we must canvass the scholarship on genealogical history.

\section{The Paradigm of Democratization}

Most historians who have contributed to our knowledge of genealogy have promoted an assumption that the driving force behind its development is the individuals engaged in genealogical research, whether professionals or amateurs. David Lowenthal, for example, has argued that the genealogical interests of the late-20th century have been a response to the "trauma" caused by migration, refugeeism, and displacement, both on a global scale and due to domestic mobility and urbanization (Lowenthal 1998, pp. 9-10). In line with this manner of thinking, historians have described the history of genealogy as a process of "democratization".

It makes sense to begin the exploration of the democratization argument with François Weil's Family Trees - the first volume to take a comprehensive view of American genealogy. Alongside Morgan's A Nation of Descendants, it remains a rare study of the longue durée of U.S. genealogical history. Weil suggests that while in "the context of postrevolutionary America's future-oriented egalitarianism, genealogy had no rightful function but challenged the dominant republican ideology", it had by the mid-19th century "become acceptable and even popular in the American republic". Because of a range of circumstances - the growing significance of the family as social units, and increased migration and urbanization - the interest in local and national history grew alongside that of lineages and pedigrees. "This entire process", Weil explains, "democratized the practice of genealogy, in effect creating a new genealogical regime dominated by middle-class, family-related, republican moral concerns while reinforcing many Americans' senses of self as individuals and citizens". Eventually, he argues-without addressing the unclear causality of his proposition - that "democratization stimulated commercialization and helped develop a market" (Weil 2013, pp. 42-43, 77; see also Taylor 1982, pp. 21-31).

In one of her earlier writings on genealogical history, Morgan shared this periodization. Arguing that the seeds of democratization were planted in Antebellum-era New England, she writes that individuals who were not of a particularly high socioeconomic standing 
attempted to use "lineage as capital" in efforts to climb the social ladder. Since it was impossible to control the social composition of persons deemed to have colonial lineage, however, Morgan asserts that genealogy troubled and thus "foreshadowed its own, later democratization" (Morgan 2010b, p. 282; see also Weil 2007; Wulf 2012). Michael Kammen, for his part, observed that genealogical engagement had spread among an Anglo-American middle class in the late-19th century, and argued that genealogy "became democratized during the 1930s" (Kammen 1991, p. 421). A paradoxical flipside of this development was the growing falsification of pedigrees that proliferated as the "demand for status among newly wealthy Americans accelerated" (Weil 2013, p. 155). Morgan's book also complicates the argument promoted by Weil-that 20th century democratization prevailed over racially informed genealogy-by demonstrating that genealogy continued to be shaped by racial, religious, gender, and class exclusivities and hierarchies. A particularly salient example was the development of eugenics in the late 19th and early 20th centuries, within which genealogy was promoted as a way of tracing biological inheritance. Together with anthropometric and mental analysis, genealogical information was one way of evaluating racial fitness, including in relation to legislation on immigration, sterilization, and miscegenation (Morgan 2021, pp. 19-51; see also, e.g., Hollinger 2003; Selden 2005).

The genealogical demos of the 19th century was, of course, limited to a small segment of white, largely Protestant Americans in the northeast. Instead of dating democratization to the late 19th or early 20th centuries, several scholars have rather identified the 1970s as the era when genealogy became democratic. As has been noted by the historian Katharina Hering, there is an "assumption ... that genealogy used to be an elitist pursuit, dominated by New Englanders, and that the practice became more democratic, and more focused on ordinary ancestors, in the course of the genealogy boom of the late 1970s" (Hering 2009, p. 3; see also Sattler 2014, p. 614). In apparent tension with his earlier argument, this shift is acknowledged by Weil, who writes that a redefinition of genealogy in "democratic and multicultural terms" did not take place until the 1970s, shaped foremost by the civil rights movement. In contrast to the first half of the 20th century, when genealogy was focused on white racial and social superiority, the post-Second World War period was according to Weil dominated by "a democratic interest in family history", where "ordinary Americans were legitimately looking for their ancestors, whether African American slaves from Georgia or immigrant maids from Finland" (Weil 2013, pp. 180-216, at. p. 179, p. 181; see also Lenstra 2015).

Indeed, the genealogical landscape changed dramatically in the 1970s. The single most important factor that scholars have emphasized was the cultural impact of Alex Haley's best-selling book from 1976, Roots: The Saga of an American Family, which the following year was turned into a blockbuster TV series (Delmont 2016; Ball and Carter Jackson 2017; see also Gerber 1977; Hijiya 1978; Chioni Moore 1994; Hudson 1994). The influence of Roots was noted by contemporaries. Historian Tamara Hareven, for example, observed in 1978 that her own moment constituted a shift "from the search for legitimization of exclusive status to a concern with emergent identity" (Hareven 1978, p. 138). The "Roots phenomenon" also changed the discourse of white ethnic genealogy, where the idea of roots became the co-opted conceptualization of European immigrant ancestry (Frye Jacobson 2008; Casey 2009; Kessel 2000; Hering 2016; Scodari 2018). While the demos of genealogy certainly expanded between the late 19th and late 20th centuries, it is not as clear how it became "democratic". The fact that, for example, an increasing number of African Americans were doing genealogy in the 1970s, created a sense of sociocultural empowerment in their everyday lives, but it does not necessarily mean that these individuals had increased power over the development of the genealogical landscape (Nelson 2016).

Others maintain that a democratic change has taken place in the post-1990s era of the Internet and genetic genealogy. The notion that genes "tell us who we are ... are now augmented by the democratization of DNA analysis", writes Alondra Nelson (Nelson 2016, p. 4). While Julia Creet has argued that the "digital revolution is another turning point" in the history of genealogy, others, such as sociologist Jackie Hogan, have declared that digital 
technologies have "revolutionized" it (Creet 2020, p. 20; Hogan 2019, pp. 67-72; see also Light 2014, p. xxi). Looking at the broader realm of public history, historian Jerome De Groot writes that the "family history movement is arguably part of a wider democratization of historical practice, imagination, and understanding", but warns that digitization could also "raise troubling issues relating to national identity, privacy, and the relationship between state and corporation" (De Groot 2015, p. 127).

Writing in 2019, and without acknowledging the genealogical activities of the last two centuries, Hogan claimed that "America is in the midst of a genealogy 'boom'", and that there is a "burgeoning interest in ancestry" today. Judging by community surveys, the self-reported interest in genealogy in the United States has grown exponentially since the 1970s. While 29\% of polled Americans reported a genealogical interest in 1977, 45\% did so by 1995 , and a staggering $87 \%$ by 2009 . The background to this increase, according to Hogan, is the "large-scale social transformations that define our age-namely, globalization, secularization, the increasing virtual nature of social life, and the sense of rootlessness these transformations provoke" (Hogan 2019, pp. 1-3). At the same time, Hogan describes the period from the late 19th to the early 20th century as the era of "democratic genealogy", since it became "practiced by a broader segment of the population, rather than simply by elites; and it came to be focused less on aristocratic pedigrees and more on the family histories of ordinary Americans" (Hogan 2019, p. 24).

A common feature of this scholarship is that the theoretical presuppositions of the argument of "democratization" are generally not explicitly accounted for or explained. An exception is Hering's dissertation, where she connects the development of genealogy from the 1890s to the 1960s to a shift in the concept of the American "people", from a notion that "tied ordinary people to ideas of race and chronological precedence", to a conceptualization that "emphasized the cultural diversity of ordinary people". "In this context", Hering writes, "the development of public interest in genealogy could be highlighted as public, popular, and democratic" (Hering 2009, p. 5). In the vast majority of studies within the scholarship, however, the trend of inarticulation is endemic.

It is important to emphasize that I share the observation that something fundamentally changed in, for example, the late-19th century and the 1970s. The question, however, is in what ways we should analytically understand how and why these changes came about. What does the democratization of genealogy really mean? Does it concern the measurable spread, need, or perceived requirement of ancestral interest among selected social groups? Does it boil down to the reasons why genealogy has been adopted by different groups (e.g., to legitimize social or racial status, which dominated the practice in the late-19th and early-20th centuries, or as an ostensibly egalitarian project of identity in the post-1970s era)? Is it, in other words, a question of the demographic composition of individuals engaged in genealogical research? Or is it a question of a presumed equal accessibility of required resources? Most importantly, what does the concept say about power as a factor of historical change?

Although imprecise as to what exactly the process of democratization has looked like, most scholars have shared the fundamental presupposition that genealogy should be studied through the perspective of individual genealogists. A focus on individual agency has likewise dominated anthropological, cultural geographical, and sociological research on genealogy, which in recent years are the disciplines within which most scholarship on genealogy has been produced. While historians have gravitated towards inquiries as to how individuals and collectives have acted toward the dead, anthropologists, sociologists, and cultural theorists have also explored perceptions about how we are affected by the dead-as in the common question "Who do you think you are?" (Light 2014, p. xxvii; see also Rosenzweig and Thelen 1998, pp. 37-62; Nash 2002). These aspects of the genealogical pursuit are further undergirded by popular culture, storytelling, everyday practices of historical engagement (e.g., Scodari 2018; Evans 2011; Kramer 2011a, 2011b), and the industry of roots tourism (e.g., Basu 2007; Schramm 2010; Reed 2015; Leite 2017). Genealogy is, however, "never simply about knowing the self" but, in the words of cultural geogra- 
pher Catherine Nash, about "degrees of connection and collective relationships-familial, national, ethnic" (Nash 2008, p. 18).

Genealogical inquiries clearly have existential repercussions for both individuals and communities, and social science scholars have been much engaged in seeking generalized answers as to how this should be explained and comprehended. The sociologist Eviatar Zerubavel, for example, has studied the "cognitive underpinnings" and the "transcultural as well as transhistorical ... principles" of genealogy, while Hogan has investigated how "our increasingly rootless society fuels the quest for authenticity, for deep history, and for an elemental sense of belonging" (Zerubavel 2012, p. 11; Hogan 2019, p. 3). Although important for comprehending the epistemological and existential workings of genealogy, the limited temporal scope of these studies makes their analyses ahistorical. A consequence of this is that genealogical work appears, in the words of Zerubavel, as being "transhistorical" and, thus, as a culturally natural phenomenon.

Instead of thinking about ancestry and genealogy as being perennial in itself, I would argue that it is more analytically productive to consider, first, what it more precisely is that we call "transhistorical" and, second, how to conceptualize that notion in relation to the decidedly modern phenomenon of genealogical practices. By doing so, the significant influence of powerful actors and interests must be brought to the fore, elevating the role of the resources, infrastructures, and media that genealogy has relied on to become an internationally popular pursuit. The agency of genealogists should surely not be overlooked, but it should also not be taken for granted. An analysis of that agency within a developing genealogical infrastructure needs to begin by exploring the human condition of ancestral longing.

\section{On Longing}

Our thinking about the dead is a longing for things absent, which is set across two temporal dimensions: one is the longing for the close dead-people we knew and whose mortal remains we care for; the other is the longing for the distant dead-people who died long ago, who we are yet unaware of, and whose mortal remains are of less import than their mortal memories. In her 1993 exploration of longing and nostalgia, literary scholar Susan Stewart defined longing as the "yearning desire, the fanciful cravings incident to women during pregnancy, belongings or appurtenances". It is "a kind of ache", enveloped in narrative (Stewart 1993, p. ix). Although longing by its very nature is something that connects the "here" and "there", in both a temporal and spatial sense, the ways in which longing has been socioculturally and existentially conceptualized have changed over time.

The nurturing of ancestry through genealogy—alongside burial sites, memorials, and personal mementos-is one of the most important cultural domains in which people today live with the dead. Throughout history, humans have buried the dead, mourned the dead, memorialized the dead, and found ways to exist among the dead. The philosophical and anthropological literature on longing is vast, and the following discussion does not intend to survey that scholarship per se. Rather, I seek to make instrumental use of research on ancestral longing as represented in two recent volumes: Being with the Dead by philosopher Hans Ruin, and The Work of the Dead by historian Thomas Laqueur. Although these books are concerned chiefly with European history and historiography, I suggest that these major studies (Laqueur's is over 700 pages long) are helpful in reframing the historical interpretation of American genealogy.

Ruin's book explores and argues for the "transcultural predicament" of "ancestrality", of the existential coexistence of the living and the dead as "a general condition and dimension of human historicity". At the heart of the inquiry is the critical interjection into human science ideas that there are "a more and a less dignified way of relating to ancestors", structured by colonial ideas about racial difference, the superiority of European civilization, and notions of spiritual progress in dealing with the dead (Ruin 2019, pp. 80, 82-83). "According to this schema", writes Ruin, "whoever learns to mourn in a rationally efficient way need not preoccupy himself with the dead, since they are gone 
and whatever effects they may have on the living are purely phantasmatic" (Ruin 2019, p. 77). According to Laqueur, the relationship between the living and the dead changed during the Enlightenment, from the sphere of divinity to that of society. "In many contexts", Laqueur argues, "history and memory replaced metaphysics" (Laqueur 2015, p. 550). It was a process exemplified by changed practices of dealing with mortuary remains, as dead bodies in the late 18th century began to be buried in cemeteries-"a huge cosmopolitan community of the dead planted in a parklike space segregated from the community of the living" - rather than in churchyards, and as the technology of cremation was introduced in the late 19th century. Cremation harbored ideas of the "purportedly disenchanted cadaver", where the ashes of the dead could be scattered in the wind or spread as a fertilizer (Laqueur 2015, pp. 84-85).

However, the disenchantment of the dead never conquered our imagination. Even the supposedly rational and enlightened systems of thought have been informed by efforts at keeping the dead "alive". Whatever the form of their mortal remains, writes Laqueur, "the presence of the dead [still] enchants our purportedly disenchanted world" (Laqueur 2015, p. 14). In proposing a different way of thinking about ancestrality, connected to a reframed conception of historical consciousness, Ruin suggests that this "pursuit of knowledge of the past remains a supreme mode of spirituality of Western global culture, through which it triumphs and reaches for transcendence" (Ruin 2019, p. 78). According to Ruin, it is paramount that we think about a society as consisting of both the living and the dead, and that "the remains of the dead are involved in the constitution of these communities in the form of an irreducible reciprocity". While this in one sense is a psychic phenomenon of desire and mourning, it is specifically "the space of the historical understood as rooted in ancestrality and being with the dead" (Ruin 2019, pp. 90-91).

Considering the history of genealogy in relation to ancestrality as a form of historical consciousness, and to the enchantment of the dead, it becomes possible to envision genealogy on a continuum of ways in which humans have related to ancestral longing. While Ruin and Laqueur are concerned with the closeness to mortal remains, the intellectual operation of skipping two, three, or many more generations in search of ancestors is also connected to a different sort of yearning: the desire for the distant dead. Since the 19th century, this yearning has been related to ideas about modernity and progress, bound up in feelings of nostalgia-the desire for a different, ostensibly slower and simpler time. In her exploration of nostalgia, Stewart outlines the relation between "the souvenir" and "the collection". In contrast to Ruin, who engages with being and historical consciousness, Stewart's inquiry is concerned with human activity. While the souvenir belongs to the realm of the close dead, the collection envelops the realm of the distant dead. The souvenir is an object that we desire of "events whose materiality has escaped us" (Stewart 1993, pp. 135, 139). But while the souvenir is intended for remembering, Stewart asserts that "the point of the collection is forgetting" - the promise that we can be "starting again in such a way that a finite number of elements create, by virtue of their combination, an infinite reverie" (Stewart 1993, p. 152). Creating the collection, however, demands a substantial amount of effort and labor. This, however, is "a labor of total magic" that is not thought of as a metaphor for "production", but as "the captured". "In the souvenir, the object is made magical", Stewart writes, "in the collection, the mode of production is made magical" (Stewart 1993, pp. 164-65).

If our close-generation ancestors are the beloved who have escaped us, our distantgeneration ancestors constitute our ancestral collections-the ultimate objects of genealogical research. There are naturally a multitude of individual conditions through which people may perceive this "infinite reverie" of ancestral longing. The orientation of longing is contingent on the influence of sociocultural context and the potentiality of lineage, prompting a tendency for longing to coalesce with the shaping or reaffirmation of a specific (ethnic, religious, etc.) identity. Today, ancestral longing often appears to be grounded in feelings of rootlessness or a will-perhaps even a sense of duty-to grasp the impact of intergenerational suffering, encompassing the brutality of slavery and genocide, or 
the hardships of transatlantic European migration (Nash 2008, pp. 59-61; Hogan 2019, pp. 12-20). This tendency has, for example, been expressed through, and bolstered by, the culture and industry of roots tourism, which have grown since the 1990s (e.g., Bruner 1996; Kelner 2010; Hjorthén 2021). In these kinds of pursuits, our distant-generation ancestors become a key component. As it may appear that the "collection" is formed by "magic"—or, analogously, that genealogy is transhistorical, existing in and of itself-historians need to investigate the "infrastructuralism" of genealogy, to borrow the concept of John Durham Peters. That is, we need to study "the boring, the mundane, and all the mischievous work done behind the scenes" (Durham Peters 2016, p. 33; see also Friedrich 2017, pp. 1-2).

\section{On Capitalization: The Case of the LDS Church}

While longing for the dead is not unique to modern history, the ways in which we-time and again-have been told that the long-dead matter as ancestors changed in the mid-19th century. The first genealogical organization in the United States was the New England Historic Genealogical Society, founded in Boston in 1845 (NEHGS). The NEHGS was established as an exclusive and elite society that was more "erudite than aristocratic" (Weil 2013, pp. 67-68). Similar to other genealogical societies that emerged in the ensuing decades-e.g., in New York in 1869 and Pennsylvania in 1892-the NEGHS catered to individuals of European descent, primarily from the British Isles. It set out to promote and facilitate research by amassing a library, issuing a periodical, and creating genealogical indices (Preface 1847, p. iv).

Since then, the modern history of genealogy has been characterized by infrastructural and technological growth. Never before in the United States have there been as many groups, institutions, and businesses telling people of the value and significance in searching for the distant dead as there are today. This includes major multi-billion-USD businesses such as Ancestry.com (Lehi, UT, USA), along with genetic genealogy corporations such as 23andMe and FamilyTreeDNA. These companies approach genealogy as a technological engineering operation of "data mining the deceased", building user-friendly interfaces and ever-expanding databases in efforts to retain existing subscribers and attract new customers (Creet 2020, pp. 4-5; see also Nash 2015, p. 50; De Groot 2015, p. 113).

During the last decade, scholars have applied various ethnographical, sociological, and cultural geographical methodologies to understand the changes and challenges of digital and DNA technologies and businesses. A significant result of these studies is how the booming industry of direct-to-consumer DNA tests has served to naturalize notions of biological inheritance. By trading in biological determinism, genetic genealogy is cultivating the message that biology defines ethno-racial belonging, thus reinforcing ideas of race as objectively distinct ancestral categories (e.g., Wailoo et al. 2012; Abu El-Haj 2012; Tallbear 2013). In addition, these businesses have also strengthened the idea that geographic origin can be detected in our DNA (Nash 2015; see also Timothy and Guelke 2008). Beyond providing resources and technologies for genealogical research, genetic genealogy businesses have sought to undergird people's longing for ancestry; they have oriented the temporal horizon of this longing further and further back in time, where today DNA haplogroups can purportedly offer you roots that are 150,000 years old; they have culturally naturalized the longing for ancestors long since passed, and they have thus reaped the profits of increased genealogical activity.

In a 1980 dissertation on genealogical organizations in the Midwest, John Patrick DuLong noted that technological developments had "pushed the genealogical organizations" to change. "One reason is that there has been no real cost to the genealogical sector in the introduction of technological innovations", DuLong wrote. "In fact, it [i.e., technology] made genealogy's tremendous growth possible" (DuLong 1986, pp. 7, 276; see also Hatton 2019). DuLong's observations about the connection between technology and genealogical activity were important and insightful, but the claim that genealogical organizations have not invested in technological development is inaccurate, as shown by the case of the LDS Church. While the LDS Church has worked with genealogy for other reasons than most 
other actors, it must be acknowledged that their activities have not, as Weil has suggested, been "outside the marketplace of genealogy", but very much integral to and entwined with its marketization (Weil 2013, p. 177; see also Cox 1984, p. 94). Rather, as noted by Morgan, "United States historians have so far insufficiently incorporated Mormon histories into more general histories" of genealogy (Morgan 2021, p. 4, see also pp. 52-67). This work has been done both directly - through interactions and cooperation with non-Mormon actors and patrons-and indirectly, by serving as a forerunner and role model in the introduction of new technologies and resources.

The significance of ancestral relations within Mormonism is grounded in scriptures from 1836 - handed down to Joseph Smith by the prophet Malachi-prompting Mormons to "turn the hearts of the fathers to the children, and the children to the fathers, lest the whole earth be smitten with a curse" (Doctrine and Covenants 2013, 27:9). Although baptisms of the dead were practiced already in the early 1840s, most of this doctrine played out within an expanded notion of family and, in particular, through polygamy (or "plural marriage", as it became known within the LDS Church). Polygamy had been a major source of tension between the United States and Utah, resulting in a series of legislation between the 1860s and 1880s aimed at curtailing polygamy, including the Edmunds-Tucker Act of 1887, which legally dissolved the LDS Church on U.S. territory. An important turning point came in 1890, when church president Wilford Woodruff had his first in a series of consequential revelations. As the Church abandoned and abolished polygamy in 1890, the path was cleared for Utah to become admitted as the 45th state of the Union in 1896 (Akenson 2007, pp. 50-63).

The LDS Church's turn to genealogy took place after its abandonment of polygamy. In 1894, church president Wilford Woodruff announced a revelation declaring that Mormons must "trace their genealogies as far as they can, and to be sealed to their fathers and mothers. Have children sealed to their parents, and run this chain through as far as you can get it" (Woodruff and Cannon 1894, p. 543). An immediate effect of this revelation was the founding of the Genealogical Society of Utah in 1894-the organization that has evolved today into FamilySearch. In a subsequent revelation by president Joseph F. Smith in 1918, Mormons were called upon to preach the gospel also to those who had not received the opportunity of hearing it during their lifetime. The Mormon missionary work for the living was thus extended to the dead, providing further incentive for genealogy (Akenson 2007, pp. 63-66).

However, doctrine alone was not enough to nudge most Mormons to actually perform genealogical research. "One should not overstate the initial pace" of the development of genealogy within the LDS Church, writes historian Donald Akenson (Akenson 2007, p. 64). The low level of activity would continue into the mid-20th century-a fact of which the LDS Church was mindful and sought ways to remedy. One way was through education. In the 1930s, the LDS Church began to include genealogical training as a requirement for teenage boys of the Aaronic priesthood-the lesser of the two common priesthoods that gather most male Mormons. Although according to Akenson the short-term impact was limited, it had long-term effects in familiarizing young Mormon males with genealogy. In 1961, genealogy was elevated to one of four functions of the LDS priesthood, alongside missionary work, welfare work, and home teaching (Allen et al. 1995; Akenson 2007, pp. 68-69). Still, most Mormons did not have the "time, skill, money, and motivation" to conduct substantial research and, by the early 1960s, there was an "acute shortage of names" submitted to the temples. According to James Allen, Jessie Embry, and Kahlile Mehr-authors of a rich and exhaustive history of the Genealogical Society of Utah-the LDS Church had two strategies to solve this problem: to adopt new technology, and to change the policy for name submission and temple work (Allen et al. 1995, pp. 174-76).

The LDS Church's educational efforts were thus developed in parallel with major infrastructural investments and theological policy changes. In an effort to offer easier service to more Mormons-saving patrons the effort of traveling to the genealogical library in Salt Lake City - the LDS Church in 1961 established the first branch library in Logan, 
Utah, which in 1964 was expanded into an international branch library system. For the first time, these libraries were open to everyone-Mormons and non-Mormons alike (Akenson 2007, pp. 69-70; Allen et al. 1995, pp. 167, 187-90). The most consequential resources in these libraries were not books, but microfilms. The LDS Church had launched its microfilm program in 1938, and expanded it to a massive and international scale after the end of the Second World War. By the 1970s, the LDS Church had gathered resources from every U.S. state and over 40 nations, resulting in a collection of over one million rolls of microfilm kept in the newly constructed Granite Mountain Records Vault outside Salt Lake City. Both literally and figuratively, the LDS Church thus possessed a "mountain of names" (Allen et al. 1995, pp. 213-32; Shoumatoff 1985).

With new unprecedented resources in place, and more in the making, the LDS Church stepped up its efforts at encouraging genealogical research. One way was through printing and distributing information to LDS Church members. A 1964 booklet directed at priesthood members (that is, most males of the LDS Church) provided instructions for how to properly motivate Mormons to pursue genealogy:

"There is a great difference between privilege and duty. In the past we have gone to great lengths in talking to our people about their duties and obligations with respect to genealogical work for their kindred dead. However, no amount of urging will bring success until people are first convinced and then converted to the need for such activity.... Instead of spending so much effort on curative measures, we should spend more time in preventive work by taking advantage of the many opportunities given to motivate our people to do research work in genealogy" (Priesthood Correlation 1964, pp. 4-5; emphasis in original).

In 1965, the LDS Church began the so-called three-generation program, which asked all Mormons to submit three generations of family group sheets. The program was intended to teach members how to accurately fill out genealogical forms, and to train Mormons to fulfil their genealogical responsibilities. The program was subsequently extended by one generation, and in 1967 merged into the four-generation program (Allen et al. 1995, pp. 190, 201-3). In April 1978, LDS Church president Spencer Kimball explained that "We want to emphasize again and place squarely on the shoulders of these individuals and families the obligation to complete the four-generation program" (Kimball 1978). By 1975, though, LDS Church leaders were faced with the discouraging insight that only $7.5 \%$ of their members had participated in the four-generation program, supposedly because genealogical research was deemed too difficult. In response, the LDS Church made concerted efforts to explain that genealogical research was simple and did not require any expertise (Allen et al. 1995, pp. 272-73). When the LDS Church in 1987 moved from using the word "genealogy" to "family history" — and changing the name of their Genealogical Library to the Family History Library - a key reason was to eliminate any friction that the somewhat opaque concept of genealogy could cause and, thus, to further lower the threshold of popular participation (Allen et al. 1995, p. 278).

The history of genealogy within the LDS Church shows how an innate longing for the close dead was, through religious doctrine, developed into a belief in the significance of the distant dead. To support temple practices relating to this belief, the LDS Church needed expanded technologies and resources. However, ancestral longing (innate and doctrinal) and research opportunities (through new media and technology) did not prove to be enough to stir genealogical activity. For this to happen, the LDS Church needed to prompt its members into action-through education (e.g., in priesthood teachings), mandated work (e.g., the three- and four-generation programs), public packaging (e.g., renaming "genealogy" as "family history"), and decades of efforts at strengthening the sense that genealogy is not a choice, but a given part of Mormon life. "If we want to stay true to our mission, which we think is actually a larger mission than for most companies", said Shipley Munson, vice president of marketing at FamilySearch, in 2010, "we need to get many, many, many more people involved in researching their families, and their family 
histories, than are involved today. ... And we are just now beginning to figure out what it takes to do that" (Munson in Creet 2020, p. 69).

Because of its spiritual foundation, the work of the LDS Church might at first sight appear to be an outlier in the genealogical landscape, but the LDS Church can only be considered a special case in the history of genealogy if one focuses on interest rather than behavior, and on the goals of capitalization rather than the ways and means by which it has been reached. Centering the work of the LDS Church in the history of modern American genealogy demonstrates the ways in which it has been pivotal for the Mormon and non-Mormon communities alike.

\section{The Capitalization of Longing}

We may be poised to live with the dead, but the nature of our ancestral longing has during the last two centuries developed significantly in tandem with the changing landscape of modern genealogy in the United States. The socioeconomic and ethno-racial demographics of people doing genealogical research have changed; the ancestors who genealogists are searching for have changed; the resources that genealogists rely on have changed, becoming more accessible and user-friendly; and the market and economics of genealogy have changed. These changes have been described as processes of democratization, implying a progressive improvement of the practice. This article has critically discussed the epistemological presuppositions of that argument and its analytical shortcomings, and through the case of the LDS Church offered an alternative conceptualization of the historical development of modern U.S. genealogy. The argument put forth is that, rather than emanating organically from the grassroots level, the changes described above have been undergirded by the active work of actors and interests that have sought to capitalize upon the perceived naturalization of ancestral longing.

What is gained from describing the modern history of genealogy in terms of the admittedly somewhat clunky concept of the "capitalization of longing", rather than the elegantly comprehensible "democratization"? First, it is important to make clear that these concepts are not in opposition. Rather, building on my critique of the democratization paradigm, capitalization of longing provides a more nuanced and precise analytical compass for understanding the trajectory of modern U.S. genealogical history; it does so by centering power in genealogy. Second, studying the capitalization of longing necessitates a diversified notion of agency, acknowledging that although genealogy is a cultural practice performed overwhelmingly at the grassroots level, its development cannot be limited to grassroots agency. Third, and unlike democratization, the concept clarifies what precisely is innate to human beings (the longing for the close dead) and what, through different devices and narratives, has been naturalized (the longing for the distant dead) through the agency of actors with power and influence (such as organizations, institutions, businesses, the media, etc.). Fourth, it questions the fundamental presupposition that it is apt to describe the history of genealogy as one of progressive development. The underlying assumption is that genealogy (like society in general?) has moved from an ostensibly undemocratic era to a democratic one, potentially continuing its path to an ever more democratic state. Not only is this a questionable assertion in the light of current societal and political developments, it also relies on an idea about progress and modernity - that, is the assumption that history invariably runs upward and forward. Considering that ideas of descent have always been at the center of American politics-ingrained in its history of settler colonialism, slavery, and immigration-and bearing in mind the volatile state of U.S. voting rights, climate change, and geopolitical tensions, this assumption is at best uncertain.

There is a danger in treating genealogy as either a contemporary or a transhistorical phenomenon. This is the danger of making all kinds of longing natural, and of treating the inevitable fulfilment of ancestral longing through genealogy as a result of magic. As with every way in which we relate to the past, genealogy is contingent and conditioned on historical circumstances. It is, at its core, a matter of choice and a creation of human agency. Being one of the most important tools for the making of community, it is all 
the more important to be mindful that genealogy is not necessarily a phenomenon of progress. Situated in a tension of innate human longing for ancestry and changing efforts to capitalize on that longing, genealogy harbors a 21st century potential that is both productive and pernicious.

Funding: This research was funded by Vetenskapsrådet (the Swedish Research Council), grant number 2016-06769. The APC was funded by the Faculty of Languages at Uppsala University.

Institutional Review Board Statement: Not applicable.

Informed Consent Statement: Not applicable.

Data Availability Statement: Not applicable.

Acknowledgments: Research for this article was conducted at the Swedish Institute for North American Studies at the Department of English, Uppsala University; the Department of History at the John F. Kennedy Institute for North American Studies, the Free University of Berlin; and the Section for History of Ideas at the Department of Culture and Aesthetics, Stockholm University. My sincere thanks go to my colleagues at all three departments. Special thanks to the anonymous reviewers, and to Dag Blanck, Adam Gilbert, Anna Källén, and Daniel Strand, who provided valuable comments on earlier versions of the article.

Conflicts of Interest: The author declares no conflict of interest.

\section{References}

Abu El-Haj, Nadia. 2012. The Genealogical Science: The Search for Jewish Origins and the Politics of Epistemology. Chicago: University of Chicago Press.

Akenson, Donald Harman. 2007. Some Family: The Mormons and How Humanity Keeps Track of Itself. Montreal: McGill-Queen's University Press.

Allen, James B., Jessie L. Embry, and Kahlile B. Mehr. 1995. Hearts Turned to the Fathers: A History of the Genealogical Society of Utah, 1894-1994. Provo: Brigham Young University Press.

Ball, Erica L., and Kellie Carter Jackson, eds. 2017. Reconsidering Roots: Race, Politics, and Memory. Athens: University of Georgia Press.

Barnwell, Ashley. 2013. The Genealogy Craze: Authoring an Authentic Identity through Family History Research. Life Writing 10: 261-75. [CrossRef]

Basu, Paul. 2007. Highland Homecomings: Genealogy and Heritage Tourism in the Scottish Diaspora. London: Routledge.

Bidlack, Russell E. 1983. Librarians and Genealogical Research. In Ethnic Genealogy: A Research Guide. Edited by Jessie Carney Smith. Westport: Greenwood Press.

Bruner, Edward M. 1996. The Representation of Slavery and the Return of the Black Diaspora. American Anthropologist 98: 290-304. [CrossRef]

Casey, Marion R. 2009. Family, History, and Irish America. Journal of American Ethnic History 28: 110-17.

Chioni Moore, David. 1994. Routes: Alex Haley's Roots and the Rhetoric of Genealogy. Transition 64: 4-21. [CrossRef]

Cox, Richard J. 1984. Genealogy and Public History: New Genealogical Guides and Their Implication for Public Historians. The Public Historian 6: 91-98. [CrossRef]

Creet, Julia. 2020. The Genealogical Sublime. Amherst: University of Massachusetts Press.

De Groot, Jerome. 2015. On Genealogy. The Public Historian 37: 102-27. [CrossRef]

Delmont, Matthew F. 2016. Making Roots: A Nation Captivated. Oakland: University of California Press.

Doctrine and Covenants of the Church of Jesus Christ of Latter-Day Saints. 2013. Salt Lake City: Church of Jesus Christ of Latter-Day Saints, vol. 27, p. 9 .

DuLong, John Patrick. 1986. Genealogical Groups in a Changing Organizational Environment: From Lineage to Heritage. Ph.D. thesis, Wayne State University, Detroit, MI, USA.

Durham Peters, John. 2016. The Marvelous Clouds: Toward a Philosophy of Elemental Media. Chicago: University of Chicago Press.

Evans, Tanya. 2011. Secrets and Lies: The Radical Potential of Family History. History Workshop Journal 71: 49-73. [CrossRef]

Everybody's Search for Roots. 1978, Newsweek, July 4.

Friedrich, Markus. 2017. Genealogy and the History of Knowledge. In Genealogical Knowledge in the Making: Tools, Practices, and Evidence in Early Modern Europe. Edited by Jost Eickmeyer, Markus Friedrich and Volker Bauer. Berlin: De Gruyter.

Frye Jacobson, Matthew. 2008. Roots Too: White Ethnic Revival in Post-Civil Rights America. Cambridge: Harvard University Press.

Gerber, David A. 1977. Haley's Roots and Our Own: An Inquiry into the Nature of a Popular Phenomenon. Journal of Ethnic Studies 5: 87-111.

Gordon-Reed, Annette. 2008. The Hemingses of Monticello: An American Family. New York: W.W. Norton \& Co.

Hareven, Tamara K. 1978. The Search for Generational Memory: Tribal Rites in Industrial Society. Daedalus 107: 137-49. 
Hatton, Stephen B. 2019. History, Kinship, Identity, and Technology: Toward Answering the Question "What Is (Family) Genealogy? Genealogy 3: 2. [CrossRef]

Hering, Katharina. 2009. "We Are All Makers of History": People and Publics in the Practice of Pennsylvania-German Family History, 1891-1966. Ph.D. thesis, George Mason University, Fairfax, VA, USA.

Hering, Katherina. 2016. Palatines or Pennsylvania German Pioneers? The Development of Transatlantic Pennsylvania German Family and Migration History, 1890s-1966. The Pennsylvania Magazine of History and Biography 140: 305-34. [CrossRef]

Hershkovitz, Aron. 2016. Genealogy and Family History through Multiple Academic Lenses: An Introduction to the Special Issue. Journal of Multidisciplinary Research 8: 5-10.

Hijiya, James A. 1978. Roots: Family and Ethnicity in the 1970s. American Quarterly 30: 548-56. [CrossRef]

Hjorthén, Adam. 2021. Old World Homecomings: Campaigns of Ancestral Tourism and Cultural Diplomacy, 1945-66. Journal of Contemporary History 56: 1147-70. [CrossRef]

Hogan, Jackie. 2019. Roots Quest: Inside America's Genealogy Boom. Lanham: Rowman \& Littlefield.

Hollinger, David A. 2003. Amalgamation and Hypodescent: The Question of Ethnoracial Mixture in the History of the United States. American Historical Review 108: 1363-90. [CrossRef]

Hudson, Michelle. 1994. The Effects of ROOTS and the Bicentennial on Genealogical Interest among Patrons of the Mississippi Department of Archives and History. Journal of Mississippi History 54: 321-36.

Jacobus, Donald Lines. 1968. Genealogy as Pastime and Profession, 2nd rev. ed. New Haven: Tuttle, Moorehouse, \& Taylor. First Published 1930.

Kammen, Michael. 1991. Mystic Chords of Memory: The Transformation of Tradition in American Culture. New York: Vintage Books.

Kelner, Shaul. 2010. Tours that Bind: Diaspora, Pilgrimage, and Israeli Birthright Tourism. New York: New York University Press.

Kessel, Barbara. 2000. Suddenly Jewish: Jews Raised as Gentiles Discover Their Jewish Roots. Hanover: Brandeis University Press.

Kimball, Spencer W. 1978. The True Way of Life and Salvation. The Church of Jesus Christ of Latter-Day Saints. Available online: www.churchofjesuschrist.org/study/general-conference/1978/04/the-true-way-of-life-and-salvation?lang=eng (accessed on 13 September 2021).

Kramer, Anne-Marie. 2011a. Kinship, Affinity and Connectedness: Exploring the Role of Genealogy in Personal Lives. Sociology 45: 379-95. [CrossRef]

Kramer, Anne-Marie. 2011b. Mediatizing Memory: History, Affect, and Identity in Who Do You Think You Are? European Journal of Cultural Studies 14: 428-45. [CrossRef]

Laqueur, Thomas W. 2015. Work of the Dead: A Cultural History of Mortal Remains. Princeton: Princeton University Press.

Leite, Naomi. 2017. Unorthodox Kin: Portuguese Marranos and the Global Search for Belonging. Oakland: University of California Press.

Lenstra, Noah. 2015. "Democratizing" Genealogy and Family Heritage Practices: The View from Urbana, Illinois. In Encounters with Popular Pasts: Cultural Heritage and Popular Culture. Edited by Mike Robinson and Helaine Silverman. New York: Springer.

Light, Alison. 2014. Common People: In Pursuit of My Ancestors. Chicago: University of Chicago Press.

Lowenthal, David. 1998. The Heritage Crusade and the Spoils of History. Cambridge: Cambridge University Press.

Morgan, Francesca. 2010a. A Noble Pursuit? Bourgeois America's Uses of Lineage. In The American Bourgeoisie: Distinction and Identity in the Nineteenth Century. Edited by Sven Beckert and Julia Rosenbaum. New York: Palgrave.

Morgan, Francesca. 2010b. Lineage as Capital: Genealogy in Antebellum New England. New England Quarterly 83: 250-82. [CrossRef] Morgan, Francesca. 2021. A Nation of Descendants: Politics and the Practice of Genealogy in U.S. History. Chapel Hill: University of North Carolina Press.

Nash, Catherine. 2002. Genealogical Identities. Environment and Planning 20: 27-52. [CrossRef]

Nash, Catherine. 2008. Of Irish Descent: Origin Stories, Genealogy, and the Politics of Belonging. Syracuse: Syracuse University Press.

Nash, Catherine. 2015. Genetic Geographies: The Trouble with Ancestry. Minneapolis: University of Minnesota Press.

Nelson, Alondra. 2016. The Social Life of DNA: Race, Reptations, and Reconciliation after the Genome. Boston: Beacon Press.

Phillips, Le Clerc. 1923. Democratic Quest for Ancestors. New York Times, October 21.

Preface. 1847. The New England Historical and Genealogical Register 1, No. 1: III-V. Boston: The New England Historic Genealogical Society.

Priesthood Correlation. 1964. Priesthood Correlation in the Genealogy Program. Church of Jesus Christ of Latter-day Saints, Print Collection of the Church History Library, Salt Lake City, UT, USA.

Reed, Ann. 2015. Pilgrimage Tourism of Diaspora Africans to Ghana. New York: Routledge.

Rodriguez, Gregory. 2014. How Genealogy Became Almost as Popular as Porn. Time, May 30.

Rosenzweig, Roy, and David Thelen. 1998. The Presence of the Past: Popular Uses of History in American Life. New York: Columbia University Press.

Ruin, Hans. 2019. Being with the Dead: Burial, Ancestral Politics, and the Roots of Historical Consciousness. Stanford: Stanford University Press.

Sattler, Julia. 2014. Genealogy and Family Trees. In The Social History of the American Family: An Encyclopedia. Edited by Marilyn J. Coleman and Lawrence H. Ganong. Los Angeles: Sage.

Schramm, Katharina. 2010. African Homecomings: Pan-African Ideology and Contested Heritage. Walnut Creek: Leftcoast Press.

Scodari, Christine. 2018. Alternate Roots: Ethnicity, Race, And Identity in Genealogy Media. Jackson: University of Mississippi Press.

Selden, Steven. 2005. Transforming Better Babies into Fitter Families: Archival Resources and the History of the American Eugenics Movement, 1908-1930. Proceedings of the American Philosophical Society 149: 199-225. [PubMed]

Shoumatoff, Alex. 1985. The Mountain of Names: A History of the Human Family. New York: Simon \& Schuster. 
Stewart, Susan. 1993. On Longing: Narratives of the Miniature, the Gigantic, the Souvenir, the Collection. Durham: Duke University Press. Tallbear, Kim. 2013. Native American DNA: Tribal Belonging and the False Promise of Genetic Science. Minneapolis: University of Minnesota Press.

Taylor, Robert M. 1982. Summoning the Wandering Tribes: Genealogy and Family Reunions in American History. Journal of Social History 16: 21-35. [CrossRef]

Taylor, Robert M., Jr., and Ralph J. Crandall, eds. 1986. Historians and Genealogists: An Emerging Community of Interest. In Generations and Change: Genealogical Perspectives in Social History. Macon: Mercer University Press.

Timothy, Dallen J., and Jeanne Kay Guelke, eds. 2008. Geography and Genealogy: Locating Personal Pasts. London: Routledge.

Tucker, Susan. 2016. City of Remembering: A History of Genealogy in New Orleans. Jackson: University Press of Mississippi.

Wailoo, Keith, Alondra Nelson, and Catherine Lee, eds. 2012. Genetics and the Unsettled Past: The Collision of DNA, Race, and History. New Brunswick: Rutgers University Press.

Weil, François. 2007. John Farmer and the Making of American Genealogy. New England Quarterly 80: 408-34. [CrossRef]

Weil, François. 2013. Family Trees: A History of Genealogy in America. Cambridge: Harvard University Press.

Woodruff, Wilford, and George Q. Cannon. 1894. The Law of Adoption. Deseret Weekly 48: 543.

Wulf, Karin. 2012. Bible, King, and Common Law: Genealogical Literacies and Family History Practices in British America. Early American Studies 10: 467-502. [CrossRef]

Zerubavel, Eviatar. 2012. Ancestors and Relatives: Genealogy, Identity, and Community. Oxford: Oxford University Press. 